by S. J. Sangode ${ }^{1}$ and K. R. Gupta ${ }^{2}$

\title{
An overview of two decades of Quaternary research in India: Some reflections based on bibliographic analysis
}

\author{
${ }^{1}$ Department of Geology, University of Pune, Pune - 411 007, India. E-mail: sangode@ unipune.ernet.in \\ ${ }^{2}$ H-44 B, Saket, New Delhi - 110017, India; E-mail: khemgupta@yahoo.com
}

In the current scenario of perceptible climatic changes and the debates over predictability of trends based on available records; it is appropriate to review the developments in the Quaternary research during past two decades. In India where the Quaternary period is richly expressed by a variety of archives in wide geographic extent; such an overview may be useful to future developments. Year-wise bibliographic analysis (since 1990) based on selective qualitative and quantitative measures such as total number of national and international publications, contributions from Universities and research Institutions, and from the Department of Science and Technology (DST)-New Delhi funded projects are especially highlighted. Further a classification of the research work into various field areas (e.g., Himalaya, Ganga basin and Bay of Bengal, Thar desert, Coastal and Marine records) is made to produce a quantitative synthesis.

The analysis derives an average of 36 publications a year, and the trend in many research field areas is significantly correlated to the DST funding. We discover two major declines in the research output: (a) during 1999-2001 and (b) since 2007. The second decline is of great concern as it contradicts to the phenomenal growth of the subject and availability of funds during recent years. The peaks and steady output during the intermediate periods is related to the seeding of national programs, multi-Institutional projects and training programs funded by DST. Considering the sympathetic relation of the research output in Quaternary geosciences to DST's support; it can be presumed that DST can play an effective role in the growth of Quaternary research in India. Further we identify and discuss three research field areas (Himalaya, Ganga basin and the Bay of Bengal) as priority areas needing attention of Quaternary geoscientists in this country. Finally, the bibliographic compilation made by this article can facilitate several analyses such as trends of output of the individual Institutes, workers and subject areas to device improvements.

\section{Introduction}

The Quaternary Geoscience has gained global attention during last two decades; particularly in the context of growing worldwide interest on climate change and related issues. The Quaternary geosciences are grown by several specializations such as paleoclimate, paleoenvironment and past global changes. Worldwide developments in terms of new data, new trends, concepts and techniques in this field during the last 20 years are remarkable. In the Indian context, during the last two decades considerable data has been produced from the Himalaya, Indo-Gangetic plains, Bengal fan, Indian ocean, Thar desert and the saline lakes of Rajasthan, Gujarat alluvium, Saurashtra and Kachchh, Peninsular River basins, and coastal records. In this scenario it is appropriate to evaluate the current status of Quaternary geosciences at the annual scales. We therefore attempt here to synthesize the bibliographic contributions in these areas during the last two decades (1990-2009) in Indian context.

\section{Methodology}

A year-wise list of published research papers (total 710 in numbers till 2009, available with authors) is presented by assigning various indices. In this list, the letters from ' $\mathrm{A}$ ' to ' $\mathrm{T}$ ' represent the years from 1990-2009 for each citation (see Table 1). The letters are assigned to the years to enable sorting by simple MS-Word commands. This is followed by the numerals from 1 to 5 to classify the work according to funding sources as below (also see Table 1);

$1=$ DST funded work; $2=$ Work that was initiated from DST funds, or the infrastructure/training made available through DST and later continued individually; 3 = Work independent of DST by Indian workers; 4 = Work independent of DST by foreign collaborations; $5=$ Independent foreign work.

Next index is again alphabetical letters from 'A' to ' $E$ ' to enable the subject/area-wise classification sorting as below;

A = Records from the Himalaya: It mainly includes the work on glaciology and the glaciogenic sediment archives (lacustrine, 
Table 1. Summary of the repository database used for bibliographic analysis

\begin{tabular}{|c|c|c|c|c|c|c|c|c|c|c|c|c|c|c|c|c|c|}
\hline \multirow{2}{*}{$\begin{array}{l}\text { Sorting } \\
\text { code }\end{array}$} & \multirow{2}{*}{ Year } & \multirow{2}{*}{$\begin{array}{l}\text { Total } \\
\text { No. of } \\
\text { Publ. }\end{array}$} & \multirow{2}{*}{$\begin{array}{c}3 \text { or } 4 \\
\text { star } \\
\text { Publ }\end{array}$} & \multirow{2}{*}{$\begin{array}{l}2 \text { star } \\
\text { Publ }\end{array}$} & \multirow{2}{*}{$\begin{array}{l}\text { Output } \\
\text { DST } \\
\text { Funded }\end{array}$} & \multirow{2}{*}{$\begin{array}{c}\text { Output } \\
\text { DST } \\
\text { Initia- } \\
\text { lised }\end{array}$} & \multirow{2}{*}{$\begin{array}{c}\text { Effective } \\
\text { DST } \\
\text { Support }\end{array}$} & \multirow{2}{*}{$\begin{array}{c}\text { Indepen- } \\
\text { dent of } \\
\text { DST } \\
\text { Indian }\end{array}$} & \multirow{2}{*}{$\begin{array}{l}\text { Indian } \\
\text { with } \\
\text { Foreign } \\
\text { collabo- } \\
\text { ration }\end{array}$} & \multirow{2}{*}{$\begin{array}{l}\text { Indepen- } \\
\text { dent } \\
\text { Foreign } \\
\text { work }\end{array}$} & \multicolumn{5}{|c|}{ Field Area } & \multirow{2}{*}{$\begin{array}{l}\text { Output } \\
\text { Univ. } \\
\text { exclu- } \\
\text { ding } \\
\text { IITs }\end{array}$} & \multirow{2}{*}{$\begin{array}{c}\text { Output } \\
\text { PRL+NIO+ } \\
\text { GSI+WIHG+ } \\
\text { BSIP+IITM+ } \\
\text { ARI+SASE) }\end{array}$} \\
\hline & & & & & & & & & & & A & B & $\mathrm{C}$ & D & E & & \\
\hline A & 1990 & 11 & 5 & 0 & 3 & 1 & 4 & 7 & 0 & 0 & 0 & 0 & 5 & 5 & 1 & 5 & 5 \\
\hline B & 1991 & 18 & 6 & 6 & 5 & 5 & 10 & 6 & 0 & 2 & 5 & 0 & 3 & 8 & 3 & 8 & 8 \\
\hline C & 1992 & 24 & 9 & 7 & 4 & 4 & 8 & 14 & 0 & 2 & 3 & 1 & 8 & 11 & 3 & 6 & 14 \\
\hline D & 1993 & 35 & 9 & 18 & 8 & 4 & 12 & 20 & 1 & 2 & 4 & 1 & 9 & 14 & 7 & 13 & 17 \\
\hline E & 1994 & 23 & 13 & 10 & 10 & 1 & 11 & 11 & 1 & 2 & 7 & 1 & 6 & 8 & 3 & 7 & 13 \\
\hline F & 1995 & 36 & 8 & 15 & 15 & 6 & 21 & 8 & 2 & 5 & 7 & 2 & 10 & 5 & 11 & 15 & 14 \\
\hline G & 1996 & 38 & 15 & 11 & 12 & 4 & 16 & 14 & 3 & 5 & 10 & 5 & 11 & 6 & 5 & 14 & 12 \\
\hline $\mathrm{H}$ & 1997 & 41 & 13 & 18 & 19 & 5 & 24 & 14 & 0 & 3 & 8 & 0 & 12 & 9 & 11 & 21 & 12 \\
\hline I & 1998 & 33 & 11 & 21 & 21 & 4 & 25 & 5 & 2 & 0 & 3 & 1 & 16 & 9 & 4 & 21 & 7 \\
\hline J & 1999 & 448 & 19 & 19 & 21 & 7 & 26 & 13 & 3 & 3 & 11 & 1 & 13 & 13 & 8 & 15 & 20 \\
\hline K & 2000 & 36 & 25 & 8 & 14 & 2 & 16 & 12 & 1 & 6 & 11 & 2 & 7 & 10 & 6 & 8 & 18 \\
\hline $\mathrm{L}$ & 2001 & 30 & 10 & 12 & 11 & 2 & 13 & 14 & 2 & 1 & 10 & 3 & 4 & 8 & 5 & 11 & 14 \\
\hline M & 2002 & 34 & 14 & 11 & 14 & 0 & 14 & 10 & 3 & 2 & 6 & 4 & 5 & 13 & 4 & 10 & 15 \\
\hline $\mathrm{N}$ & 2003 & 52 & 23 & 21 & 28 & 5 & 33 & 9 & 5 & 6 & 17 & 7 & 12 & 14 & 3 & 16 & 22 \\
\hline $\mathrm{O}$ & 2004 & 50 & 19 & 23 & 27 & 14 & 41 & 6 & 1 & 2 & 16 & 4 & 10 & 10 & 8 & 19 & 19 \\
\hline $\mathrm{P}$ & 2005 & 47 & 22 & 17 & 30 & 4 & 34 & 7 & 0 & 6 & 17 & 11 & 7 & 7 & 5 & 9 & 19 \\
\hline Q & 2006 & 51 & 22 & 25 & 25 & 6 & 31 & 15 & 2 & 3 & 14 & 5 & 5 & 16 & 11 & 10 & 21 \\
\hline $\mathrm{R}$ & 2007 & 52 & 28 & 23 & 34 & 6 & 40 & 8 & 1 & 3 & 16 & 10 & 8 & 9 & 9 & 15 & 26 \\
\hline S & 2008 & 29 & 18 & 9 & 12 & 9 & 21 & 5 & 1 & 1 & 9 & 1 & 5 & 10 & 3 & 12 & 9 \\
\hline $\mathrm{T}$ & 2009 & 23 & 16 & 5 & 10 & 3 & 13 & 6 & 2 & 3 & 11 & 3 & 2 & 2 & 4 & 7 & 8 \\
\hline
\end{tabular}

Field Areas: $\mathrm{A}=$ Records from the Himalaya and adjoining mountains; $\mathrm{B}=$ Records of Paleomonsoon Variation and Sediment flux-Climate Relations;

$\mathrm{C}=$ Records from Thar Desert and other Continental deposits of Rajasthan and Gujarat; D = Marine and Coastal Records; $\mathrm{E}=$ Other Peninsular records.

3-star: International journals of high reputation in the respective field (mostly of impact factor >1) and 4-star: 'Nature' and 'Science' publications.

2-star: Current Science, Geological Society of India and other widely circulate/cited journals.

fluvial/fluvio-lacustrine), tree ring and pollen records focusing upon paleoclimate as well as tectono-climatic relations.

$B=$ Records of paleomonsoon variation and sediment fluxClimate relations: This is a more regional aspect specifically dealing with the long term paleomonsoon records based on sediment flux to Bengal and Indus fan basins and their linkages as climate proxies. The records from Indo-Gangetic Plains and Dun Intermontane basins with their relation to paleoclimate-paleomonsoon are also accounted in this field.

$\mathrm{C}=$ Records from Thar desert and other continental deposits of Rajasthan and Gujarat: Records from deserts, playa lakes, alluvial plains, fluvial and other continental deposits of Rajasthan and Gujarat are documented in this field. It also includes the records from Narmada basin, Saurashtra and Kachchh.

D = Marine and Coastal Records: The coastal and marine records (including deep sea) in relation to sea level changes and paleomonsoon variation are accounted in this field.

$\mathbf{E}=$ Peninsular records: This includes monsoon-paleomonsoon variation using proxy and fluvial response, and the geoarcheological records.

The next evaluation is made by stars (asterisk at the end of each citation) indicating qualitative analysis according to the journal citation/impact factors as below:

No Star = Proceedings and books from local or lesser known publishers or the In-house journals.

One Star = Official records like GSI (records and memoirs) and other lesser circulated Indian journals.
Two Star $=$ Current Science, Geological Society of India and other widely circulated/cited Indian journals.

Three Star = International journals of high repute in the respective fields (mostly of impact factor $>1$ ).

Four Stars = Publications in 'Nature' and 'Science'.

Further we analysed the individual project completion reports (PCR's) of DST in order to find the relation of fund allocation with publication output as auxilliary information to the interpretation of graphical trends described below.

\section{Overview Based on Graphical Trends and Statistics}

The average total number of yearly publications (all inclusive) is 35.5 with maximum number of 52 during 2003 and 2007 (see Tables 1 and 2). The year 2007 is notable for its highest number of three/ four star publications (total 28) that may partly be influenced by the release of special (edited) volume of Quaternary International (vol. 159) on 'Quaternary fluvial systems of India'. This year also records the maximum output from DST funded work, output from Institutes, and predominance of the field area A(Himalaya and related). Therefore it appears to be the benchmark year when majority of the DST projects have matured producing good output. It is however followed by a continuous (?) downward trend for the succeeding years 2008 and 2009 (Fig.1). The statistical mean of output of the 'DST 
Table 2. The descriptive statistics for bibliography presented

\begin{tabular}{|c|c|c|c|c|c|c|c|c|c|c|c|c|c|c|c|c|}
\hline Parameter & $\begin{array}{l}\text { Total } \\
\text { No. of } \\
\text { Publ. }\end{array}$ & $\begin{array}{c}3 \text { or } 4 \\
\text { star } \\
\text { Publ }\end{array}$ & $\begin{array}{l}2 \text { star } \\
\text { Publ }\end{array}$ & $\begin{array}{l}\text { Output } \\
\text { DST } \\
\text { Funded }\end{array}$ & $\begin{array}{l}\text { Output } \\
\text { DST } \\
\text { Initia- } \\
\text { lised }\end{array}$ & $\begin{array}{c}\text { Effective } \\
\text { DST } \\
\text { Support }\end{array}$ & $\begin{array}{c}\text { Indepen- } \\
\text { dent } \\
\text { of DST } \\
\text { Indian }\end{array}$ & $\begin{array}{l}\text { Indian } \\
\text { with } \\
\text { Foreign } \\
\text { collabo- } \\
\text { ration }\end{array}$ & $\begin{array}{l}\text { Indepen- } \\
\text { dent } \\
\text { Foreign } \\
\text { work }\end{array}$ & \multicolumn{5}{|c|}{ Field Area } & $\begin{array}{l}\text { Output } \\
\text { Univ. } \\
\text { exclu- } \\
\text { ding } \\
\text { IITs }\end{array}$ & $\begin{array}{c}\text { Output: } \\
\text { PRL+NIO+ } \\
\text { GSI+WIHG+ } \\
\text { BSIP+IITM+ } \\
\text { ARI+SASE) }\end{array}$ \\
\hline Mean & 35.5 & 15.25 & 13.95 & 16.15 & 4.6 & 20.75 & 10.2 & 1.5 & 2.85 & 9.3 & 3.1 & 7.9 & 9.35 & 5.65 & 12.1 & 14.65 \\
\hline Median & 35 & 14.5 & 13.5 & 14 & 4 & 18.5 & 9.5 & 1 & 2.5 & 9.5 & 2 & 7.5 & 9 & 5 & 11.5 & 14 \\
\hline Mode & 35 & 9 & 18 & 10 & 4 & 21 & 14 & 1 & 2 & 11 & 1 & 5 & 8 & 3 & 15 & 14 \\
\hline SD & 12.04 & 6.58 & 7.02 & 9.06 & 3.12 & 10.84 & 4.15 & 1.32 & 1.87 & 4.89 & 3.18 & 3.68 & 3.50 & 3.05 & 4.83 & 5.60 \\
\hline Kurtosis & -0.73 & -0.89 & -0.94 & -0.81 & 3.42 & -0.84 & -0.30 & 1.04 & -0.62 & -0.70 & 1.29 & -0.40 & -0.14 & -0.71 & -0.73 & -0.61 \\
\hline Skewness & -0.22 & 0.25 & -0.15 & 0.43 & 1.36 & 0.46 & 0.58 & 0.92 & 0.46 & -0.02 & 1.36 & 0.43 & -0.03 & 0.65 & 0.44 & 0.11 \\
\hline Range & 41 & 23 & 25 & 31 & 14 & 37 & 15 & 5 & 6 & 17 & 11 & 14 & 14 & 10 & 16 & 21 \\
\hline Minimum & 11 & 5 & 0 & 3 & 0 & 4 & 5 & 0 & 0 & 0 & 0 & 2 & 2 & 1 & 5 & 5 \\
\hline Maximum & 52 & 28 & 25 & 34 & 14 & 41 & 20 & 5 & 6 & 17 & 11 & 16 & 16 & 11 & 21 & 26 \\
\hline Count & 20 & 20 & 20 & 20 & 20 & 20 & 20 & 20 & 20 & 20 & 20 & 20 & 20 & 20 & 20 & 20 \\
\hline Confidence & 5.63 & 3.08 & 3.29 & 4.24 & 1.46 & 5.07 & 1.94 & 0.62 & 0.88 & 2.29 & 1.49 & 1.72 & 1.64 & 1.43 & 2.26 & 2.62 \\
\hline
\end{tabular}

funded work' makes more than half of the total number of publications (see Table 2). Contributions from collaborations and independent foreign work is less in the total number but is significant in some of the research field areas like 'A', 'B' and ' $D$ '. In the field area 'B' although some of the world's thickest Quaternary sedimentation is available as continental to marine records (Ganga basin, Bengal fan, Indus fan and the Intermontane basins), the output is low compared to that in other discrete Quaternary basins. The notable output from the Ganga basin and the intermontane (Dun) basins is related to sedimentology, tectonics/neotectonics and climate. Studies related to sediment flux and climate relation for the field area B is particularly less attended. The field area $\mathrm{C}$ of arid zone research (Thar deserts and adjoining continental records) has shown phenomenal growth during the first decade producing new teams fuelled by DST. This field is remarkable from the point of University-Institutional collaborations as well as independent output from University departments (although consistent only with few departments).

The overall output from the University departments is lower than the Institutional outputs. Further only selective university departments have maintained the research in Quaternary Science during these two decades. Amongst Institutes, the Physical Research Laboratory (PRL) in fact made significant contributions during previous decades (80's and early 90's) but remained stagnant afterwards with declining trend towards the end of the later decade. Somewhat similar trends can also be noted for the National Institute of Oceanography (NIO). Universities with enough student manpower and Institutes having good infrastructure (and sample records such as sediment cores) can definitely improve the situation particularly by inducting collaborations and dissertation programs.

The 'total number of publications' do correlate significantly with 'DST funding' and the field area 'A' (see Table 3). It also correlate significantly with the 'two star' and the 'three and four star'

Table 3. The correlation matrix based on correlation coefficient $\left(R^{2}\right)$ for the parameters analysed in this study

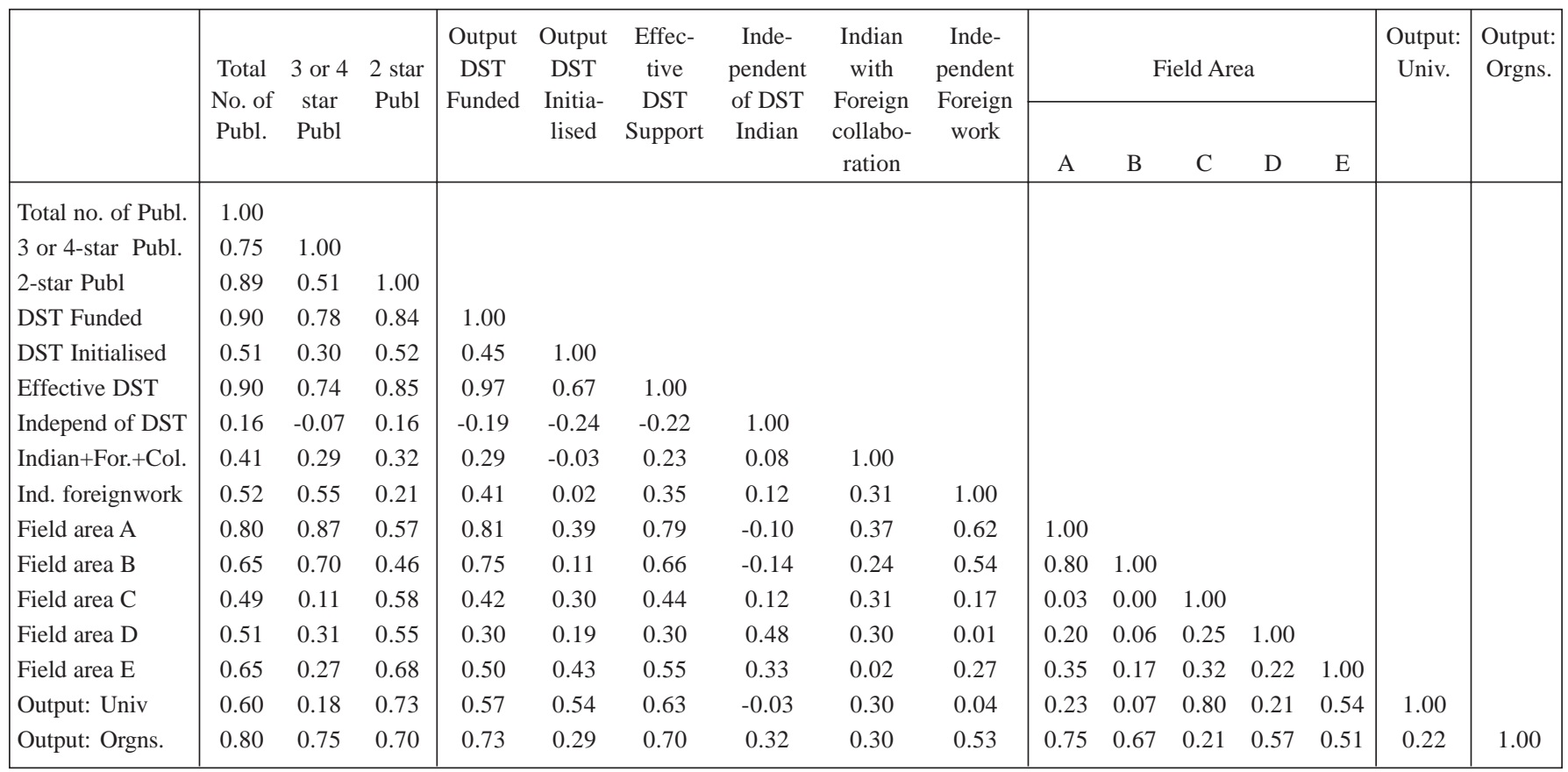




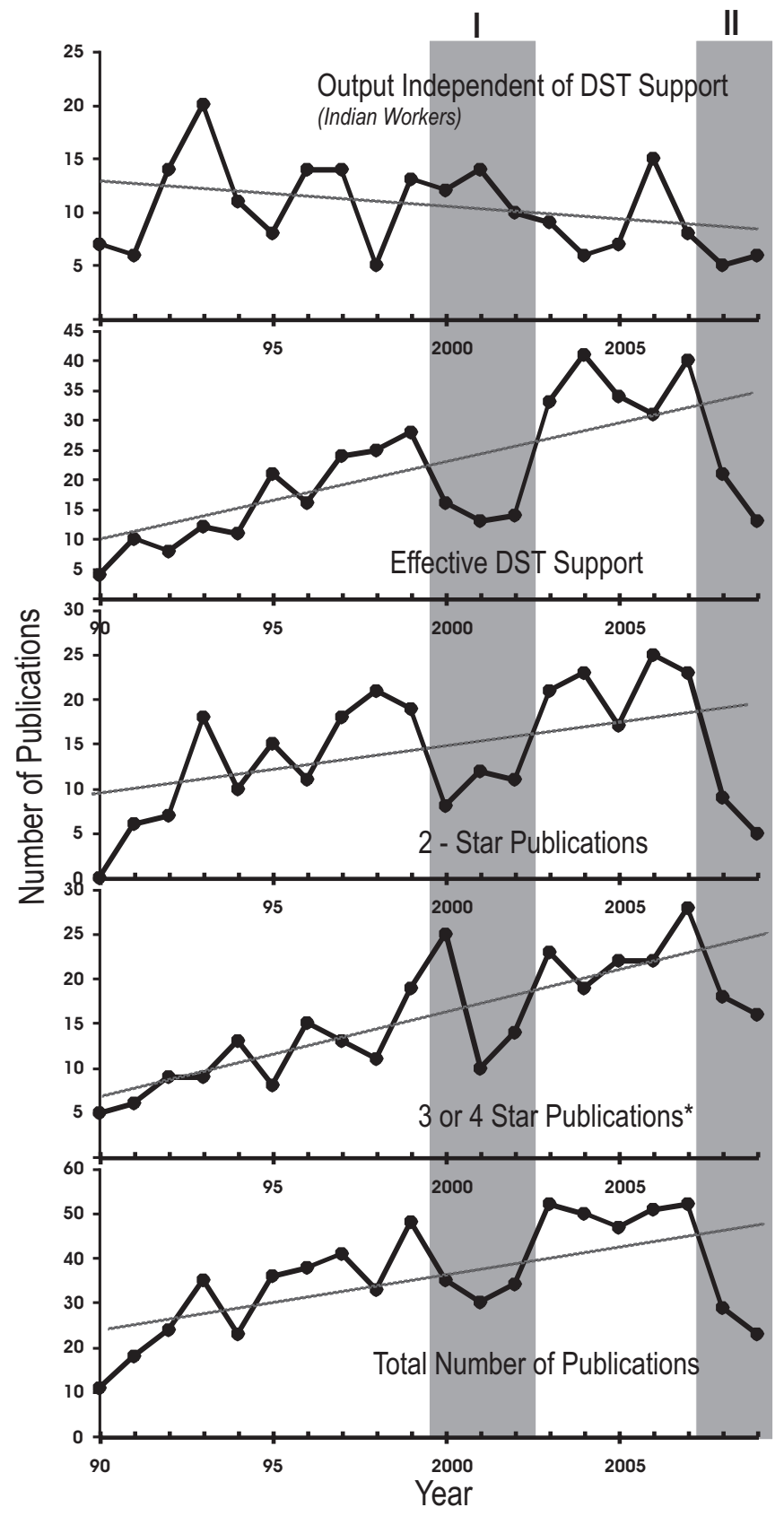

Figure 1. Year-wise graphical trend of various parameters used during this study. The database used is available as repository. The grey shaded areas indicate two downtrends. The detail analysis of trends is discussed in the text.

publications. However, a more detailed analysis in the field area 'A' indicates that there is significant contribution from independent foreign work accounting for the 'three and four star' publications. This is also evident from the good correlation between the field area 'A' and the 'foreign work'. Outputs from Universities show significant correlation with the field area ' $\mathrm{C}$ ' and the 2-star publications. The output from Institutes is also greatly influence by the DST support in this correlation. The linear trend lines (in Fig.1) indicate a general increasing trend with terminal drop except for the output independent of DST by Indian workers. The year-wise variation indicates two dips; (a) after 1999 till 2001 and (b) after 2007. If we assume that the trends are controlled by DST funding, then the first downfall at 2001 coincides with the lower number of funded projects during 19952000. The increased funding after 2000 appears to have raised the publications output. Considering the phenomenal growth of the subject, however, the decline in the research output after 2007 is contradictory to the growing demand/the phenomenal growth of the subject elsewhere. We envisaged various reasons for this as below; (i) The knowledge on Quaternary records in India is passing through a transition from 'reporting and identifying the proxy' to the high resolution connection to climatic variations. In this scenario, the Quaternary research community is facing limitations by the geological complications of signatures and the absence of good chronologies. (ii) Quaternary being highly interdisciplinary subject, it needs teamwork effort by a proper combination of expertise individually deeply involved into the problem. Such team efforts (if present) are under decline during the second decade. (iii) Limited number of expertise and reputed laboratories to produce chronology is the major constrain in obtaining the dates.

Research area-wise, the trend lines (in Fig. 2) show steady growth in the area 'A' and 'B', stagnancy in the area 'D' and decline in ' $\mathrm{C}$ '. The downfall after 2007 is related to the downfall in the total number of publications marked by the decline 'II' in Fig.1. In the year-wise trend the decline 'I' of Fig.1 matches well with the decline in the field area 'C' of Fig.2 (i.e., Arid zone research of Thar, Gujarat area). Further Fig. 3 depict that the output from Institutes is steady but the same is declining for University departments. This should be a serious concern for the departments apart from the overall post - 2007 decline.

\section{A Brief Overview of Year-wise Reflections}

The initial years of 90's are related to the awareness and growth of the Quaternary sciences as one of the emerging branch. It was yet to identify as a thrust area by majority of the Institutes and University departments during this time. However in this scenario, the year 1990 have marked good output from the Thar desert and Gujarat alluvium. The most notable amongst publications during 1990 is the 'Nature' publication from PRL group on oxygen isotope study of the marine sediment cores indicating weaker summer monsoon and stronger winter monsoon during LGM. The year 1991 produced probably the first reliable thermoluminescence (TL) date with well constrained paleoclimate record from the loess-paleosol sequence of Thar (by PRL group). Work on calcretes and coastal sediments from University departments is greatly appreciated during the year. Some work on the Chhota Singri glacier of Lahaul by Wadia Institute of Himalayan Geology (WIHG) is notable. More TL dates from Thar, work on Karewas, and the Indian ocean sediments by PRL group is appreciable for the year 1992. Good attempts from NIO, GSI; and continued research output from University departments which were productive during earlier period is noted for the year 1992. The year 1993 marks a prolific work on Thar, Gujarat (Saurashtra) and Narmada basin by majority of the groups from Universities, GSI and PRL. Release of the special volume on Quaternary Geology by Current Science has raised the publication number during 1993. The work from lake sediments and glaciogenic deposits of Himalaya is reported during this year. Work on peat from southern Peninsula, miloilites and forams from Saurashtra and Kachchh, and some sea level related publications 


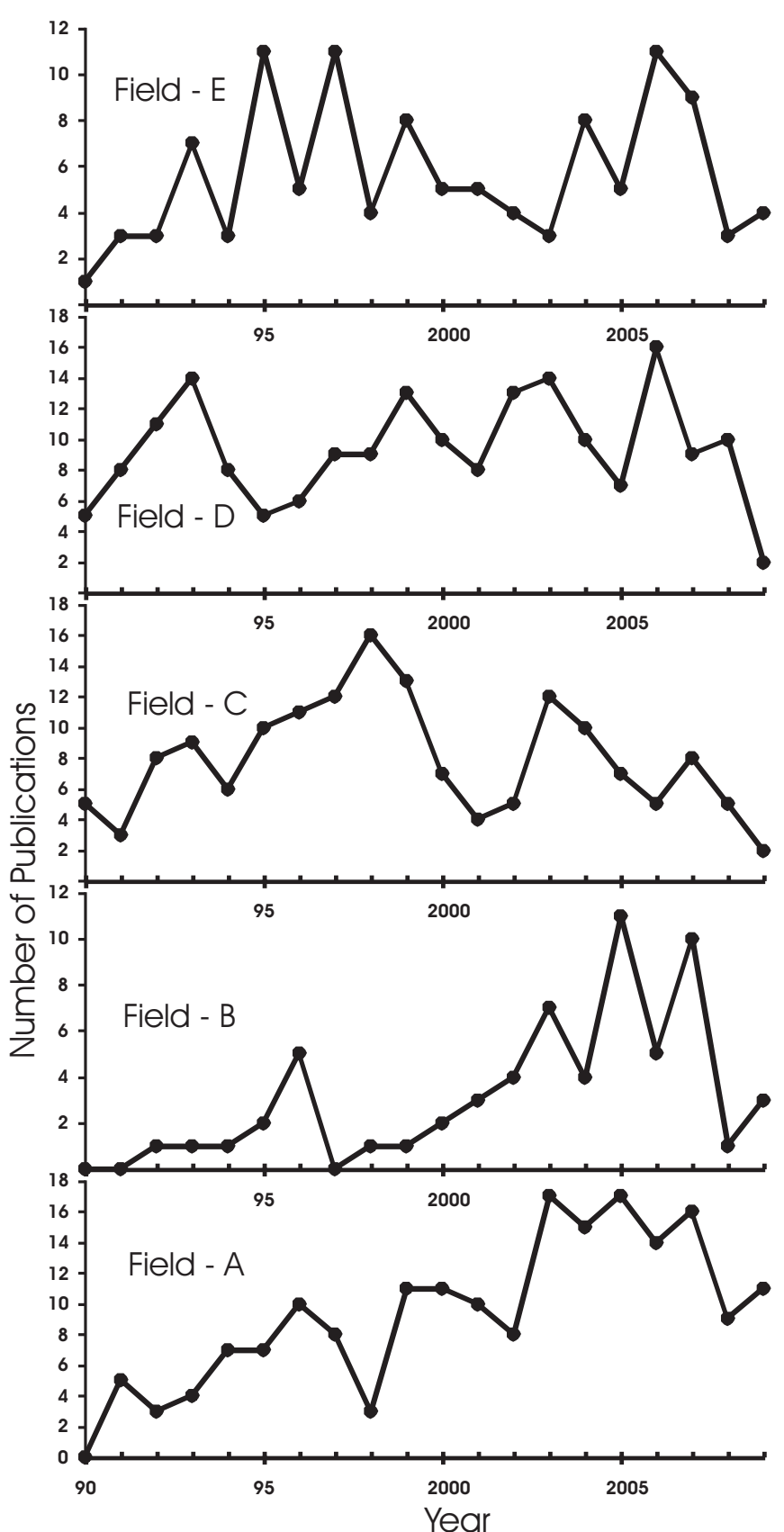

Figure 2. Research field area-wise yearly trends depicting the research fields (alphabets denoted under Table 1).

are highlighted during the year. An independent foreign work on century scale paleomonsoon variation published in Nature is worth to mention. Yet this year marks only few 3-star publications but majority of 2-star publications produced. The year 1994 can be noted for new data on tree rings with dendrochronology approach, work on glacial snout fluctuations and the publications on deep sea records and coastal deposits. Research from Thar, Gujarat, Saurashtra, Narmada and Ganga basins has been the continuous endeavor through 1995. Publication of data on marine sediments by NIO and PRL, apart from the consistent output on coastal sediments from University departments can be noted for the year. The publication of Memoir of Geological Society of India on 'Quaternary environments and Geoarcheology of India' raised the graph during 1995. The year 1996 shows significant output from the University departments, both in quantity and quality in retrospect to all the above fields. Independent work by foreign teams on the Himalayan glaciers and glaciogenic sediments, and marine sediments is noteworthy during this year. This year marks little representation from PRL, NIO, and GSI; but some output from WIHG, BSIP and IITM. Similar trends continued for the years 1997-99 with good output from University departments like M.S. University-Baroda, Kumaon University-Nainital, Delhi University, Cochin University, IIT-Kanpur and Kharagpur, Pune University and the Deccan college Pune groups. The year 2000 shows good outcome from the Institutes (NIO, PRL, IITM, WIHG, BSIP and ARI). Publications on the solar forcing, ISM, ENSO and some work on geoarcheology can be highlighted for the year 2002 . Consistent output from Kachchh, Saurashtra, Gujarat, Ganga plain, general work related to paleomonsoon and the new concepts of relationship between erosion-uplift and precipitation in the Himalaya (by foreign teams) are the highlights for the year 2003. The year 2004 shows good output on the Himalayan glaciology, paleohydrology from Peninsular India, monsoon records from the Arabian sea and paleoclimatic studies from the Ganga alluvium. The years 2005 and 2006 mark the contributions from the Ganga basin over sedimentologic and geomorphic aspects. Work on Narmada sediments and the Himalayan glaciers are also notable during this year. However, a general declining trend for the publications in Quaternary studies can be seen for the Institutes (PRL, NIO, WIHG and BSIP). The graph of 2007 is much influenced by the release of special volume of Quaternary International specifically producing good work from Ganga and the Intermontane Dun basins. This year also accounts for consistent output from the University departments over Narmada, Tapi and Godavari basin and the Quaternaries of west coast. The years 2008 and 2009 marks the release of glacier Atlas of Himalaya besides good contributions on the Ganga basin, coastal records and Arabian sea although in a general declining trend after 2007.

Further we present a selective overview for the research field areas (A) and (B) as below.

\section{Field Area A: Records from the Himalaya}

The Himalayan region has been of great interest to the global community for studying the relationship of tectonics and climate, monsoonal variability, and several feedback mechanisms e.g., related to Westerlies, Inter-tropical convergence zone (ITCZ), upliftment and erosion. Pristine paleoclimatic records in the Himalaya are therefore significant in this context. The glacial, glacio-fluvial and lacustrine archives in the Himalaya are some of the most significant and accessible paleoenvironmental/paleoclimatic continental records available on the earth.

Studies on glacial retreat during the past two decades in the Himalaya indicate that even by taking in account the minimum rate of $20 \mathrm{~cm} / \mathrm{yr}$, a glacial cover of $>4000 \mathrm{~m}^{2}$ can be vacated within a year. Such changes can greatly alter the hydrology of the glacial fed rivers in the Indo-Gangetic plains. It is therefore crucial to monitor the glaciated regions in the Himalaya by more advanced methods like satellite imagery (e.g., ASTER) and well equipped field stations, besides the field documentation. The agencies like SASE, GSI and WIHG are dedicated to such work but with little participation from University departments. Broad based programs are therefore essential to integrate the sediment archives with modern observations and creating inputs to advanced modeling. Major lacuna of dating the sediment archives also needs to be removed on priority. 

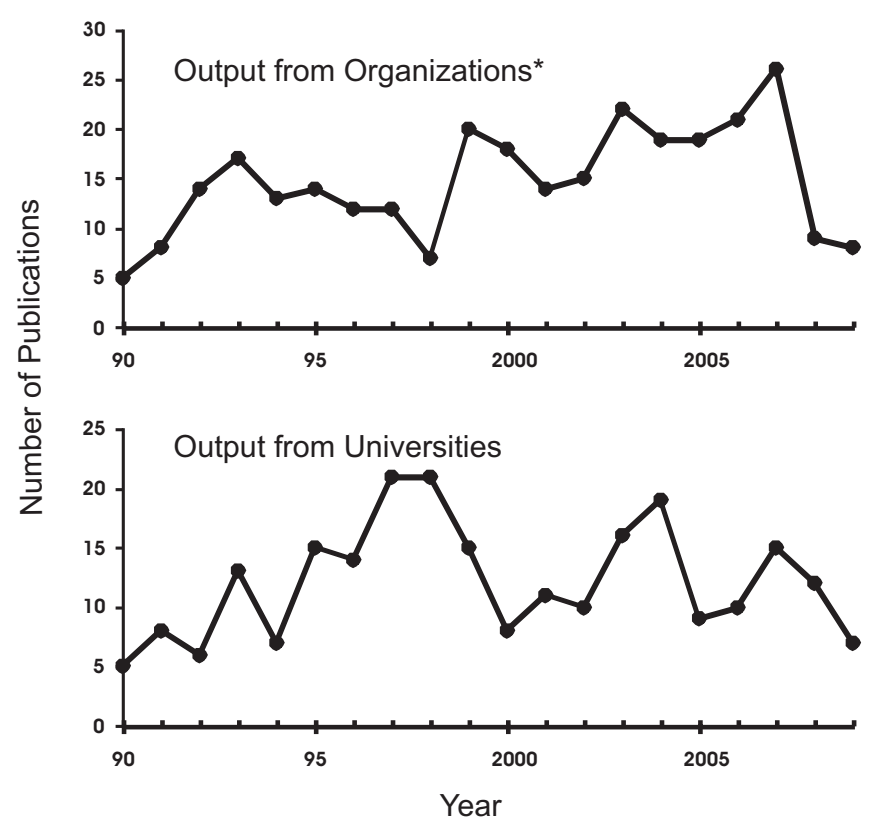

Figure 3. The yearly trend of total number of publication output for research Institutes and Universities.

During last five years, this field area show major contributions independently from foreign teams on various aspects of glaciology, glacial geomorphology and glaciogenic sediments. One of the reasons for less representation by Indian workers may be that majority of the workers in this country are from the tropical (non-glaciated) region, and have limited access and expertise over the glaciated regions. Further the topic of glaciaology and glacial geomorphology, in general and the Himalayan glacialogy in particular, is not well represented in the University syallabi, reducing the chances of developing young interests.

\section{Field area B: Records of paleomonsoon variation and sediment flux-climate relations}

India receives about $80 \%$ of its annual rainfall from the SW monsoon during four months of June to September and its agrobased economy is dependent upon the monsoon rainfall. Therefore, any predictions related to monsoon variability are of utmost importance to this country. Consequently, the records of paleomonsoon variation have been of great interest to Quaternary scientists in India. The sediment records of paleomonsoon can be broadly classified into 'sediment flux' as against the 'high resolution paleomonsoon proxy'. The sediment flux provides a regional mass balance relationship between monsoonal intensity and sediment production (and transport), while the proxies are useful as high resolution records. It is essential to integrate the sediment flux data with proxy, based on understanding developed from instrumental data, If the two are of similar time resolution.

Although, Indian subcontinent is gifted with large integrated Quaternary basins of Ganga, Bengal fan and the Himalaya; majority of the Indian work during past two decades have focused more upon the Ganga basin. Attempts to integrate the Himalaya and Bengal fan with the Ganga basin sedimentation are rare. Sediments of the Ganga basin and intermontane valleys of the Himalayan foothills have been studied in great detail especially during the later decade by independent teams from IIT Kanpur, Lucknow University, IIT-Roorkee, Delhi
University and WIHG. Several reviews have come up during these two decades producing detailed account of the sedimentation relation to tectonic and climatic factors, highlighting the complications and future scope of work. It is time to integrate the evolution of Ganga basin more ambitiously on several aspects from its relation to the Himalayan glacial stages to the deep marine turbidites in the Bengal fan. This however needs accurate chronology from the well documented Quaternary archives of Himalaya, Intermontane basins, Ganga basin and the sediment cores from Bengal fan. Sediment 'source to sink' approaches can help to develop detailed mass balance models for sediment transfer to the Bengal fan with careful assessment on tectonic and climate controlled factors.

\section{The Role of DST}

During the past two decades DST has funded several minor and major research projects of direct/indirect relevance to the Quaternary geosciences. During these years it has also developed special programs for University Departments besides being the regular funding agency to autonomous Institutes like WIHG and BSIP those includes Quaternary as one of their thrust areas. During 80's DST evolved some multi-disciplinary and multi-institutional programmes related to Quaternary research that focussed upon; (i) Deep Sea Fans of Bay of Bengal, (ii) Himalayan Glaciology, (iii) Palaeoclimate Research, and (iv) Arid Zone Research. It should be noted that these are still some of the most demanding areas, even after 28 years.

After organizing several interaction meetings of geoscientists in the country, DST identified 'challenging areas' in its $8^{\text {th }}$ five years plan (published in Mem. Geol. Soc. India, no. 18, pp. 1-24, 1990). This includes some of the important topics on Quaternary e.g., Coastal Geomorphology and dynamics in relation to Sea Level Changes, Bengal and Nicobar Fans, Quaternary Stratigraphy including study of Fluvial and Glacial Systems, Neogene/Quaternary Boundary, Pleistocene-Holocene Boundary, and Palaeoseismology. Thus, DST has encouraged several inter-institutional and multidisciplinary programs and projects by liberal funding in the Quaternary geosciences.

In the mid-90's, the previously formulated 'Challenging Areas' and other related coordinated programmes of DST were reviewed by a committee of experts. Based on this review and interaction a document entitled "Vision for R\&D in Earth Sciences" was evolved by DST. Few themes/areas of future research activities were identified that had direct relevance to Quaternary research under the heads of: (i) Reconstruction of palaeoenvironments, palaeoclimates and past global changes and (ii) Earth Science applications for societal needs (e.g. geohydrology, environmental geology and natural hazards). Apart from these special efforts, DST has regularly funded several major and minor research projects, symposia and workshops related to Quaternary geosciences to the University and Institutes. Remarkable amongst these are the setting up of infrastructure and chronologic laboratories and the long term programs like 'Shallow Subsurface Studies'. On these accounts therefore it is essential to consider the leading role of DST in the development of Quaternary sciences in this country.

In the incident of the 2007 decline in publication depicted in the Figs. 1 and 2, and the sensitivity of publication output to DST funding; the DST can play an effective role to revitalize the growth of Quaternary sciences in this country. A serious concern is therefore 
required to decide the priorities and formulate new programs in this context with a major thrust to bring out younger talent and matured teams. Identification of both, long term and short term priorities, revision of University syllabus, formulation of accountable teams, induction of new geology departments in the geologically significant regions can be some of the effective solutions. Another important issue is that of documentation; where majority of the Quaternary journals are of international nature and do not signify the local and undated records. The local records can have greater significance to understand the complexity of the system and needs to be assessed carefully before conclusive regional inferences. In this regard there are no dedicated Quaternary journals available at the national level for quick reporting. Hence new journals are to be inducted within the country, focussed at issues related to Quaternary geosciences.

Quaternary Earth science has a great scope that concern large segments of the population focussing upon some of the critical issues like natural hazards, risk evaluation, water resources. Therefore interfacing geological and agricultural sciences makes a priority to address the issues like climate change. During the last two decades, Quaternary research in India has undergone great technological and methodological transformation partly in alignment with the international community but without much development in the field documentation. The local signatures can be of great significance in understanding the complexities of the regional signatures in the given climate-geo-eco- system. It is therefore essential to evaluate and

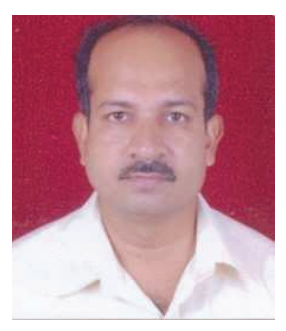

S.J. Sangode started his carrier in 1990 at the Indian Institute of Geomagnetism, Mumbai; later moved to Wadia Institute of Himalayan Geology, Dehradun (1991-2006). During this period he worked on magnetostratigraphy of the Pliocene and Pleistocene Siwalik sequences of the Himalaya. After 1997, he focussed on the mineral magnetic aspects of the Siwalik paleosols. Since 1999 he is working on the Quaternary sediments in the Himalaya (lacustrine and intermontane fluvial), Ganga basin, Bay of Bengal and the Godavari. He joined as faculty to the Geology Department, University of Pune during 2006; and since then working in the coastal sediments of west coast of India, urban soils and the Quaternaries in the LadakhKarakorum Himalaya. identify integrated long term and short term goals to decide the priorities. Robust lateral correlation with chronologies is a major first step in this context within each field area/basin/domain to identify the varied response times of climate system. Efforts on understanding the tectono-climatic signatures instead of separating the two may be useful for several basins at longer time scales. As the Quaternary geosciences address to many socio-economic aspects; in the country like India all the efforts are to be pursued in a synergetic mode by effective communication amongst government, industrial and academic agencies.

\section{Acknowledgements}

We are most thankful to the concerned scientists for supplying relevant information. KRG is thankful to DST, New Delhi for providing the opportunity to be associated with the DST funded project on 'Database on funding of earth science projects by DST to RDC New Delhi'. Authors greatly acknowledge Prof. S. K. Tandon for a detailed and critical review that improved the thoughts as well as overall presentation of manuscript. Prof. V. S. Kale is acknowledged for his critical pre-review of an earlier version of this manuscript providing useful suggestions. SJS acknowledges Head, Department of Geology for support provided during this work. Authors also acknowledge Prof. Y. Enzel for review and suggestions.

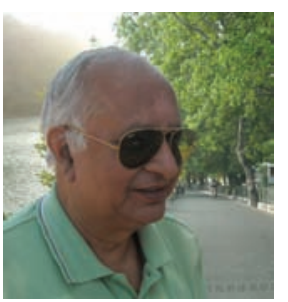

K.R. Gupta started his carrier in the Department of Geology and Mining in the J\&K Government during 1973, later he joined Wadia Institute of Himalayan Geology in 1978. He has been a constant driving force in the geological community in India for over two decades of his carrier in the Department of Science and Technology (DST), New Delhi. From Senior Scientific officer to the Advisor in DST, he coordinated several National programs and Committees for funding and monitoring of DST projects with intense interaction amongst research communities of almost two generations in this country. He has a wide experience from policy matters to developing multidisciplinary programs in the earth sciences in India. 